\title{
Využivání služeb kariérového poradenství žáky středních odborných škol ${ }^{1}$
}

\author{
LENKA HLOUŠKOvÁ
}

\begin{abstract}
Abstrakt: Význam služeb kariérového poradenství je obvykle spojován s jednotlivci, ale v této studii je pozornost zamèrena na jeden ze společenských cílù těchto služeb, konkrétně na otázku, jak mohou služby kariérového poradenstvi prispivat k sociálni spravedlnosti ve společnosti.

Cílem je identifikovat roli služeb kariérového poradenstvi pri stretu se sociálnimi nerovnostmi.

Metoda: Text vycházi z dat sbiraných dotaznikem v prüběhu brezna a dubna 2018 mezi žáky poslednich ročniku denni formy studia na střednich odborných učilištich a střednich odborných školách $v$ Jihomoravském a Moravskoslezském kraji. Role kariérového poradenství jsou rozkrývány na základě charakteristik žákủ a statisticky významných rozdilu mezi těmi, kteři služeb využili, a tèmi, kteři služeb nevyužili, stejně tak jako s oporou o korelace mezi pohlavím, subjektivním hodnocením vzdělávacích výsledkư, typem ukončeni studia, vzdělávacími aspiracemi a využiváním služeb.

Výsledky: $Z 3096$ respondentů se s odbornikem radilo $14 \%$ źáki̊. Častěji služeb využili žáci, kterí v prūběhu svého studia zmènili školu, kteři hodnotili své studijni výsledky na prvními stupni klasifikačni stupnice, deklarovali zlepšováni studijnich výsledkư v prüběhu studia, a ti, kteři maji predstavu o své studijni neboli pracovni budoucnosti. Naopak žáci, kteři hodnoti své studijni výsledky jako dostatečné nebo nejsou se svými výsledky spokojení, častěji plánuji využit služeb odbornika. Jednorázově poradce vyhledali častěji ti, kteři nespojuji svou budoucnost s dosavadnim oborem studia, ale maji aspiraci dosáhnout vyššího stupně vzdèláni, než které právě končí.

Závèr: Uvedená zjištèni naznačuji, že kariérové poradenstvi má potenciál prispivat k sociálni spravedlnosti prostřednictvím tři rolí, které se odviji od charakteristik žákü-klientì a jejich divvodu vyhledáni služby.
\end{abstract}

Kličová slova: kariérové poradenství, sociálni spravedlnost, žáci odborného vzdèlávání, vyšši sekundárni vzdèlávání.

\section{ÚvoD}

Odborné vzdělávání na úrovni vyššího sekundárního vzdělávání má v ČR dlouhou tradici a dodnes tímto segmentem vzdělávání prochází většina populace. I když v důsledku snižování síly populačních ročníků dochá-

\footnotetext{
${ }^{1}$ Text je jedním z výstupů projektu Career adaptability of vocational upper-secondary school graduates during the school-to-work transition podporovaného GA ČR (GA18-07537S).
} 
zelo $^{2} \mathrm{v}$ posledních šesti letech $\mathrm{k}$ poklesu počtu žáků a tím i absolventů ve všech typech středního odborného vzdělávání, stále odborným vzděláním prochází více než $70 \%$ žákovské populace (Vojtěch \& Chamoutová, 2018). Srovnáme-li podíl žáků, kteří studují v odborném vzdělávání $\mathrm{u}$ nás, $s$ podílem těchto žáků $\mathrm{v}$ ostatních evropských zemích, tak ČR opakovaně obsazuje první př́čku (CEDEFOP, 2018; Trhlíková \& Úlovcová, 2010).

Cílem odborného vzdělávání (na úrovni ISCED 353, 354) je př́íprava k výkonu konkrétních povolání, nebo $\mathrm{v}$ obecnější rovině $\mathrm{k}$ uplatnění na trhu práce $\mathrm{v}$ souladu s měnícími se požadavky zaměstnavatelů. Vyvažování nesouladu mezi vzdělávací nabídkou, požadavky zaměstnavatelů a kompetencemi absolventů představuje specifický úkol kariérového poradenství v odborném vzdělávání, kterým se liší od kariérového poradenství poskytovaného v rámci jiných typů a stupňủ vzdělávání (Kuczera, 2010; Hooley, 2014). Úkoly kariérového poradenství, které se v odborném vzdělávání týkají jednotlivců a mají obecnější dopady na strukturu a fungování společnosti (CEDEFOP, 2018), vytvárí další specifika těchto služeb, která však nejsou př́liš výzkumně zmapována (Hooley, 2014).

V návaznosti na to je pochopitelné, že se $\mathrm{v}$ poslední době stále více zpochybňuje teze o tom, že využívání služeb kariérového poradenství vede $\mathrm{k}$ reprodukci existujících sociálních nerovností ve společnosti (srov. CEDEFOP, 2010). Naopak dnes se začínají definovat vazby mezi kariérovým poradenstvím a různými koncepty sociální spravedlnosti (Hooley, Sultana \& Thomsen, 2018; Sultana, 2014) a otevírá se diskuze o potenciálu kariérového poradenství vyrovnávat vzdělávací i sociální nerovnosti, stejně jako se diskutuje o tom, které kariérové poradenství je tzv. sociálně spravedlivé.

Přispět $\mathrm{k}$ této diskuzi je cílem i tohoto textu. Prvním krokem $\mathrm{k}$ uvedenému cíli je zjistit, kteři žáci středního odborného vzdělávání využívají služeb kariérového poradenství a jaké důvody je $\mathrm{k}$ tomu vedou.

\section{SPECIFIKA ODBORNÉHO \\ VZDĚLÁVÁNÍ A SLUŽEB KARIÉROVÉHO PORADENSTVÍ V ČR}

Odborné vzdělávání na úrovni ISCED 353, 354 př̀edstavuje v ČR diferencovaný systém, což samo o sobě vyvolává otázku, jestli struktura odborného vzdělávání vytváří dostatečně „efektivní“ sít, která dokáže zvyšovat zaměstnatelnost absolventů a snižovat u nich riziko nezaměstnanosti, nebo naopak komplikuje sociální mobilitu a tím přispívá $\mathrm{k}$ reprodukci sociálních nerovností (srov. Veselý \& Matějů, 2010). $\mathrm{Z}$ pohledu jednotlivce však diferencovaný systém vytváří pestrou paletu vzdělávacích př́ležitostí, $z$ nichž si lze vytvořit různé vzdělávací cesty. Variabilita vzdělávacích cest se odvijí od stupňủ vzdělání,

${ }^{2}$ Od školního roku 2017/2018 začíná mírně stoupat počet nově nastupujících ke studiu (Vojtěch \& Chamoutová, 2018). 
počtu škol a existující nabídky vzdělávacích oborů.

Důležitým ukazatelem a současně specifikem odborného vzdělávání v ČR je počet studentů $v$ programech směrujících $\mathrm{k}$ dosažení jednotlivých stupňů vzdělání. ${ }^{3}$ Do oborů středního odborného vzdělávání s výučním listem (kategorie $\mathrm{H}+\mathrm{E}) \mathrm{v}$ denní formě studia ve školním roce 2017/2018 nastoupilo $29 \%$ žáků odcházejících ze základních škol, do oborů ukončených maturitní zkouškou (kategorie $\mathrm{M}$ i L dohromady) nastoupilo $41 \%$ žáků a v oborech ukončených maturitou $s$ odborným výcvikem začalo studovat $6 \%$ žáků (Vojtěch \& Chamoutová, 2018). Údaj ze školního roku 2017/2018 není z dlouhodobějšího hlediska nijak výjimečný. Naopak nižší procento studujících $\mathrm{v}$ oborech ukončených výučním listem $\mathrm{v}$ porovnání s obory ukončenými maturitní zkouškou je dlouhodobějším trendem (CEDEFOP, 2018; Kantorová, 2015).

V každém stupni vzdělání existují desítky rámcových vzdělávacích programů, které vymezují podmínky vzdělávání $\mathrm{v}$ jednotlivých skupinách oborů (Nařízení vlády, 2010) klasifikovatelných podle mezinárodní klasifikace zaměstnání - ISCO. Podle rámcových vzdělávacích programů si školy vytvářejí školní vzdělávací programy, které jsou pro účely statistiky označovány pojmem školobor. ${ }^{4}$ Ukazatelem pestrosti vzdělávací nabídky může být právě počet školoborů. „Nejvíce školoborů realizovaných v prvních ročnících v denní formě ve školním roce 2016/2017 je v kategorii $\mathrm{H}$ (1770), těsně následován kategorií M (1604). S velkým odstupem následují školobory kategorie E (554), L/0 (389)..." (Chamoutová, Vojtěch \& Chomová, 2017, s. 31).

Jen letmá úvaha o proporcích mezi počtem žáků $\mathrm{v}$ jednotlivých stupních středního odborného vzdělávání a počtem školoborů naznačuje, že pro systém odborného vzdělávání v ČR je typický nízký počet studentů $\mathrm{v}$ jednotlivých studijních oborech (srov. CEDEFOP, 2018). To nemusí být z hlediska řízení a financování systému výhodou, ale mělo by to být výhodou z hlediska jednotlivců, kteří tak mají možnost realizovat své volby. Vzdělávací př́íležitosti, které žáci využívají, lze vysledovat $\mathrm{v}$ individuálních vzdělávacích trajektoriích, přičemž platí, že čím pestřejší nabídku vzdělávacích příležitostí systém nabízí, tím větší variabilita vzdělávacích drah je možná. Pestrost vzdělávací nabídky a variabilita vzdělávacích drah klade zvýšené nároky na informovanost a orientaci jedinců v existujících možnostech, což posiluje význam kariérového poradenství z hlediska zajištění spravedlivého přístupu $\mathrm{k}$ informacím a pomoci všem, kteří takové informace a pomoc potřebují.

Charakter a zaměření služeb kariérového poradenství v ČR vychází ze

\footnotetext{
3 Školský zákon $(2004,2018)$ v odborném vzdělání rozlišuje tři stupně vzdělání: střední vzdělání, střední vzdělání s výučním listem (kategorie $\mathrm{H}+\mathrm{E}$ ), střední vzdělání s maturitní zkouškou zahrnující střední odborné vzdělání (kategorie M) a střední vzdělání s maturitní zkouškou i s odborným výcvikem (kategorie L0).

${ }^{4}$ Školobor = obor vyučovaný konkrétní školou. Počet školoborů =počet realizovaných kombinací školy a oboru vzdělání (Chamoutová, Vojtěch \& Chomová, 2017).
} 
systémově nastavených opatření, která upravují činnosti různých typů poskytovatelů. Nabídka služeb kariérového poradenství pro žáky základních i středních škol se odvíjí od nabídky služeb školního poradenského pracoviště na té které škole, kde žáci studují. Kromě služeb školního poradenského pracoviště mohou žáci využít služeb poboček Úřadu práce ČR, pedagogicko-psychologických poraden, vysokoškolských poraden, služeb neziskových organizací, případně krajských zařízení či soukromých poskytovatelů.

Všichni uvedení poskytovatelé by měli být schopni žákům poskytnout orientaci $\mathrm{v}$ jejich dalším směřování (career guidance), holisticky pojatou individualizovanou pomoc při zvládání překážek či obtiží spojených s kariérovým rozhodováním, stejně jako podporu kariérového rozvoje (career counselling). Nedílnou součástí těchto činností je tzv. personalizovaná práce $s$ informacemi (např. Borgen \& Hiebert, 2006). Naopak poskytování nepersonalizovaných informací (career advising), které Borgen a Hiebert (2006) vyčleňují zvlášt vedle služeb typu career guidance a career counselling, není v ČR spojeno $s$ žádným $\mathrm{z}$ výše uvedených typů poskytovatelů. Tuto službu totiž "poskytují" veřejně př́stupné online nástroje, informační portály či databáze (např. Infoabsolvent. cz, Národní soustava povolání, vysokeskoly.cz).

Kromě toho by měli být všichni žáci základních i středních odborných škol připravováni „na svět práce“ během vyučování (career education). Tento typ služby je zakomponován do rámcových vzdělávacích programů (dále jen RVP), konkrétně je obsažen ve vzdělávací oblasti Člověk a svět práce $\mathrm{v}$ př́ípadě RVP pro základní vzdělávání (RVP $Z V, 2017)$ a v průřezovém tématu $\mathrm{v}$ př́padě $\mathrm{RVP}$ pro střední odborné vzdělávání. Tyto části RVP mají u žáků podpořit rozvoj dovedností spojených s kariérovým rozhodováním, plánováním a řízením kariéry, čímž by se měla saturovat řada potřeb žáků ve vztahu ke kariérovému rozhodování i kariérovému rozvoji.

Problémů, s nimiž se ale uvedené služby kariérového poradenství musí vyrovnávat, je celá řada: nedostatečné personální zabezpečení, nedostatečné a nejisté financování a materiální zázemí služeb, nejasná provázanost jednotlivých typů služeb a v důsledku toho mj. netransparentnost systému $\mathrm{z}$ hlediska uživatelů služeb, absence systému monitorování efektivity a kvality služeb. Základní překážkou pro rozvoj systému služeb kariérového poradenství v ČR i specificky $v$ odborném vzdělávání je absence empirických dokladů o využívání těchto služeb, které je opomíjeným tématem i v zahraničí (srov. Balin \& Hirschi, 2010).

\section{Metodologie}

Tato studie je založena na vyhodnocení několika dotazníkových položek, které byly součástí dotazníkové baterie vytvořené pro účely první vlny sběru 
dat v rámci longitudinálního výzkumu mapujícího kariérovou adaptabilitu u adolescentů. Dotazníková baterie byla distribuovaná žákům absolventských ročníků denní formy studia na středních odborných školách a středních odborných učilištích v Jihomoravském a Moravskoslezském kraji. ${ }^{5}$ Dotazníky se k žákům dostávaly skrze školy, na kterých aktuálně studovali a jejichž vedení bylo ochotno na výzkumu spolupracovat, tj. distribuovat dotazníky mezi žáky a př́padně vytvořit prostor pro jejich vyplnění. $O$ tom, jestli žáci budou vyplňovat tištěný dotazník, nebo elektronickou verzi dotazníku, rozhodovaly možnosti škol a preference ředitelů škol. Sběr dat probíhal v březnu a dubnu 2018.

Využití služeb kariérové poradenství bylo operacionalizováno do podoby otázky: Radilla jste se s nějakým odbornikem, co byste chtělla dëlat po ukončeni středni školy? Odbornikem je myšlen naprr. výchovný poradce, školni psycholog, pracovnik úradu práce či v personálni agenture, poradce na vysoké škole apod. Tato otázka měla v dotazníku charakter položky s možností jedné volby ze čtyř (ano, opakovaně; ano, jednorázově; ne, ale plánuji; ne, a neplánuji). $\mathrm{Na}$ otázku odpovědělo 3096 studentů ve věku 18-26 let. Dívky jsou ve vzorku zastoupeny $46 \%$. Celkový počet studentů reprezentuje 44 středních škol, které nabízejí různé vzdělávací obory. $Z$ hlediska stupňů vzdělání je ve vzorku zastoupeno $37 \%$ žákủ, kteří budou končit své studium výučním listem, 58 \% žáků směřovalo $\mathrm{k}$ maturitní zkoušce a $5 \%$ žáků by mělo ukončit studium maturitní zkouškou i výučním listem.

Pro zjištění rozdílů mezi respondenty byla položka vyhodnocena v původním znění a následně upravena do podoby binární proměnné. $V$ obou případech byly rozdíly mezi skupinami testovány testem dobré shody chí-kvadrát a v některých př́padech F-testem. Interpretace výsledků testu chí-kvadrát jsou založeny na adjustovaných reziduích testovaných na hladině významnosti $\alpha=0,05$. V některých př́padech je těsnost vztahu mezi proměnnými vyjádřena na základě hodnot Cramerova V.

Pro ty, kteří odpověděli na otázku, že služeb kariérového poradenství využili, následovala položka $s$ tvořenou odpovědí ve znění: Co bylo hlavním impulzem pro to, že jste vyhledalla poradce? Pro účely další analýzy jsem pracovala s volnými odpověd'mi od 320 respondentů, jejichž odpovědi jsem rozřadila podle typu služeb kariérového poradenství (career guidance, career counselling), a následně jsem každý soubor odpovědí kategorizovala zvlášt technikou otevřeného kódování (Strauss \& Corbinová, 1999).

\footnotetext{
${ }^{5}$ Výběr krajů byl do jisté míry formálním opatřením pro získání respondentů, ale prioritou bylo, aby kraje byly srovnatelné v parametrech, které mají vazbu ke kariérové adaptabilitě. Konkrétně jde o dva údaje: podobnost ve vývoji počtu středních škol i počtu žáků (Chamoutová et al., 2017, s. 8-9; MŠMT, 2017) a shodnou vyšší míru nezaměstnanosti absolventů, než je celorepublikový průměr (MPSV, 2017). V obou krajích byli požádáni o spolupráci při distribuci dotazníků k žákům ředitelé všech škol.
} 
KDO VYUŽÍVÁ A KDO SPí̌ PLÁNUJE VYUŽITÍ SLUŽEB KARIÉROVÉHO

\section{PORADENSTVÍ?}

Tabulka 1 dokladuje, že služeb kariérového poradenství využilo $14 \%$ respondentů a $\mathrm{z}$ toho pouze $4 \% \mathrm{z}$ nich opakovaně. Vyžívání služeb se neliší ve zkoumaných krajích, což by mohlo signalizovat, že dostupnost služeb kariérového poradenství pro žáky je v obou krajích srovnatelná. Je zajímavé, že stejnou míru využití služeb kariérového poradenství (14\%) prokázalo šetření mezi dospělými ve věkové kategorii 18-30 let, které proběhlo v roce 2012 (Hloušková, 2012). Šetření z roku 2011, které probíhalo mezi žáky posledních ročníků studia na středních odborných školách a středních odborných učilištích, zahrnovalo otázku, zda žáci při svém rozhodování využili rad odborníků. Tato otázka však vypovídá o míre vlivu jednotlivých typů poskytovatelů kariérového poradenství na rozhodování žáků, z níž se dá usuzovat i na míru využití služeb. Míra vlivu odborných služeb se pohybovala v rozpětí $2,7-7,2 \%$ žáků podle typu poskytovatele (Š́astnová \& Drahoňovská, 2012, s. 19) a je jasné, že by míra využití služeb měla být vyšší než míra vlivu.

Proč nevyužívá služeb kariérového poradenství více žáků odborného vzdělává- ní? Jednu možnou odpověd' reprezentuje názor, že žáci svým rozhodnutím nastoupit ke studiu v určitém typu odborného vzdělávání nasměrovali svou další kariéru, a proto $\mathrm{v}$ průběhu studia na středních odborných školách / učilištích již podporu ze strany kariérového poradenství nepotřebují (srov. OECD, 2004). Mnohem prozaičtější vysvětlení vyplývá z dostupnosti a př́stupnosti služeb a $\mathrm{z}$ ochoty žáků/rodičů tyto služby vyhledat. To, jestli žák do svých 18 let služby kariérového poradenství využije nebo ne, je ovlivněno jeho vzdělávacími aspiracemi, které jsou spojeny se sociálním prostředím, v němž vyrůstá, stejně jako jeho spokojeností s dosavadními volbami, charakterem vzdělávací dráhy i se vzděláváním na konkrétní škole. V neposlední řadě záleží i na tom, jakou zkušenost mají či jaký postoj zaujímají $\mathrm{k}$ těmto službám vrstevníci/spolužáci i jejich rodiče (srov. Hlad’o \& Drahoňovská, 2012).

Údaj o využití služeb kariérového poradenství mủže vyznívat tak, že žáci, kteří služeb využili, tvoří homogenní skupinu, ale dále $v$ textu se zaměŕme na to, jak tomu je v tomto vzorku (srov. CEDEFOP, 2018; Trhlíková \& Úlovcová, 2010). V následující části textu je tedy věnována pozornost proměnným, které nejen specifikují skupinu těch, kteří služeb využili, ale $\mathrm{v}$ souvislosti s využíváním/nevyužíváním služeb

Tab. 1. Využívání služeb kariérového poradenství

\begin{tabular}{|c|c|c|c|c|}
\hline ANO, opakovaně & ANO, jednorázově & NE, plánuji & NE, neplánuji & Celkem \\
\hline $\mathbf{1 3 7}$ & $\mathbf{3 1 0}$ & 599 & 2050 & 3096 \\
$(\mathbf{4}, \mathbf{4} \%)$ & $(\mathbf{1 0} \%)$ & $(19,4 \%)$ & $(66,2 \%)$ & $100 \%$ \\
\hline
\end{tabular}


Tab. 2. Využívání služeb kariérového poradenství podle pohlaví

\begin{tabular}{|l|c|c|c|}
\hline Četnost & Chlapci & Dívky & Celkem \\
\hline ANO, opakovaně & $82(60 \%)$ & $55(40 \%)$ & $137(100 \%)$ \\
\hline ANO, jednorázově & $160(52 \%)$ & $150(48 \%)$ & $310(100 \%)$ \\
\hline
\end{tabular}

kariérového poradenství mohou být překážkou pro uplatňování principu sociální spravedlnosti ve společnosti. Konkrétně jde o pohlaví, způsob ukončení studia, studijní výsledky (prospěch) a vzdělávací aspirace.

Vyšší procentní zastoupení chlapců mezi těmi, kdo deklarují, že využili služeb kariérového poradenství (tab. 2), je dána vyšším počtem chlapců $\mathrm{v}$ odborném vzdělávání obecně, stejně jako ve výzkumném vzorku (54 : 46 \%). Pohlaví tedy nelze považovat za „př́činu“, která by vedla $\mathrm{k}$ využívání služeb kariérového poradenství.

Jinak tomu je $\mathrm{v}$ případě ukončení studia (tab. 3). Ti, kteří využili služeb kariérového poradenství opakovaně, jsou z $52 \%$ žáci oborů ukončených výučním listem. V porovnání s maturanty statisticky významně častěji deklarují opakované využití služeb, stejně jako statisticky významně častěji plánují tyto služby využít $(\mathrm{p}<0,01)$. To by naznačovalo, že žáci učebních oborů mají komplexnější zakázky, které nelze „vyřrešit“v rámci jednoho poradenského setkání, nebo z nějakého důvodu potřebují, aby je služby kariérového poradenství provázely $\mathrm{v}$ průběhu jejich studia nebo v období přechodu ze školy na trh práce.

Z hlediska uplatňování principu sociální spravedlnosti je otázkou, jestli má kariérové poradenství potenciál eliminovat předčasné odchody ze vzdělávání/studia. Předpokladem $\mathrm{k}$ tomu je, aby těchto služeb využívali žáci, jimž hrozí předčasný odchod ze studia. $\mathrm{Za}$ rizikové $\mathrm{v}$ tomto smyslu lze považovat žáky, kteří v průběhu studia změnili školu nebo studijní obor (srov. Hloušková, 2014). Jedinou statisticky významnou změnou, která se z okruhu uvedených proměnných (tab. 4) váže $\mathrm{k}$ využivání služeb kariérového poradenství, je změna školy $(\mathrm{p}<0,01)$. Dá se tedy předpokládat, že změna školy se stává jedním z možných důvodů využití služeb kariérového poradenství.

Tab. 3. Využívání služeb kariérového poradenství podle způsobu ukončení studia

\begin{tabular}{|l|c|c|c|c|}
\hline & $\begin{array}{c}\text { Ukončení } \\
\text { výučním listem }\end{array}$ & $\begin{array}{c}\text { Ukončení } \\
\text { maturitou }\end{array}$ & $\begin{array}{c}\text { Ukončení } \\
\text { maturitou } \\
\text { i výučním listem }\end{array}$ & Celkem \\
\hline $\begin{array}{l}\text { ANO, } \\
\text { opakovaně }\end{array}$ & 71 & $\begin{array}{c}61 \\
(41,8 \%)\end{array}$ & $\begin{array}{c}5 \\
(3,6 \%)\end{array}$ & $\begin{array}{c}137 \\
(100 \%)\end{array}$ \\
\hline $\begin{array}{l}\text { ANO, } \\
\text { jednorázově }\end{array}$ & 111 & 183 & 17 & 310 \\
$(35,8 \%)$ & $(58,7 \%)$ & $(5,5 \%)$ & $(100 \%)$ \\
\hline
\end{tabular}


Tab. 4. Využívání služeb kariérového poradenství podle změn ve vzdělávací dráze

\begin{tabular}{|l|c|c|c|c|c|}
\hline & Žádná změna & Změna školy & Změna oboru & $\begin{array}{c}\text { Změna školy } \\
\text { i oboru }\end{array}$ & Celkem \\
\hline $\begin{array}{l}\text { ANO, } \\
\text { opakovaně }\end{array}$ & $\begin{array}{c}109 \\
(81 \%)\end{array}$ & $\begin{array}{c}\mathbf{1 0} \\
(\mathbf{7} \%)\end{array}$ & $\begin{array}{c}6 \\
(4 \%)\end{array}$ & $\begin{array}{c}10 \\
(7 \%)\end{array}$ & $\begin{array}{c}135 \\
(100 \%)\end{array}$ \\
\hline $\begin{array}{l}\text { ANO, } \\
\text { jednorázově }\end{array}$ & $\begin{array}{c}243 \\
(79 \%)\end{array}$ & $\begin{array}{c}\mathbf{1 4} \\
(\mathbf{5} \%)\end{array}$ & $\begin{array}{c}23 \\
(7 \%)\end{array}$ & $\begin{array}{c}29 \\
(9 \%)\end{array}$ & $\begin{array}{c}309 \\
(100 \%)\end{array}$ \\
\hline
\end{tabular}

Další okruh pomyslných př́ícin předčasných odchodů ze vzdělávání souvisí se školními výsledky žáků. Za rizikové v tomto smyslu lze považovat žáky, kteří opakují ročník, jejich prospěch je v posledním roce studia klasifikován jako nedostatečný, nebo se prospěch v průběhu studia zhoršuje (srov. Hloušková, 2014). V uvedeném vzorku nesouvisí využívání služeb kariérového poradenství s opakováním/neopakováním ročníku. Jinak tomu je v př́ípadě subjektivního hodnocení aktuálního prospěchu. Ti, kteří hodnotí své aktuální studijní výsledky jako výborné, velmi dobré a dostatečné (tab. 5), využívají služeb častěji než ostatní, a naopak ti, kteří hodnotí své studijní výsledky jako dobré a nedostatečné, častěji než ostatní služeb nevyužívají $(\mathrm{p}<0,05)$. Je zajímavé, že ti, kteří hodnotí své studijní výsledky jako nedostatečné, častěji plánují služeb využít. Otázkou ale zůstává, jestli plán využít služeb kariérového poradenství je reálným plánem, nebo spíš sociálně žádoucí odpovědí.

Kuczerová (2010) uvádí, že dovednosti spojené $s$ utvářením kariéry (např. sebeuvědomění, porozumění jednotlivým prŕležitostem) jsou spojeny s výkony žáků ve škole v tom smyslu, že ti, kteři dosahují lepších studijních výsledků, jsou ochotnější vyhledávat rady a informace a mají jasnější představu o své budoucnosti. Z tohoto úhlu pohledu se zdá, že ti, kteří hodnotí své aktuální studijní výsledky prvními stupni klasifikační stupnice a v průběhu studia se jim studijní výsledky zlepšují (tab. 6), využitím služeb kariérového poradenství $(\mathrm{p}<0,01)$ posilují svou dobrou pozici ve vzdělávání.

Naopak ti, kteří hodnotí své studijní výsledky jako dostatečné nebo vníma-

Tab. 5. Vztah mezi aktuálními studijními výsledky a využíváním služeb kariérového poradenství

\begin{tabular}{|l|c|c|c|c|c|c|}
\hline & Výborné & $\begin{array}{c}\text { Velmi } \\
\text { dobré }\end{array}$ & Dobré & Dostatečné & $\begin{array}{c}\text { Nedosta- } \\
\text { tečné }\end{array}$ & Celkem \\
\hline $\begin{array}{l}\text { ANO, } \\
\text { opakovaně }\end{array}$ & $\begin{array}{c}\mathbf{1 5} \\
(\mathbf{1 1} \%)\end{array}$ & $\begin{array}{c}8 \\
(6 \%)\end{array}$ & $\begin{array}{c}51 \\
(38 \%)\end{array}$ & $\begin{array}{c}61 \\
(45 \%)\end{array}$ & $\begin{array}{c}1 \\
(0 \%)\end{array}$ & $\begin{array}{c}136 \\
(100 \%)\end{array}$ \\
\hline $\begin{array}{l}\text { ANO, } \\
\text { jednorázově }\end{array}$ & $\begin{array}{c}22 \\
(7 \%)\end{array}$ & $\begin{array}{c}\mathbf{2 4} \\
(\mathbf{8} \%)\end{array}$ & $\begin{array}{c}122 \\
(41 \%)\end{array}$ & $\begin{array}{c}129 \\
(43 \%)\end{array}$ & $\begin{array}{c}4 \\
(1 \%)\end{array}$ & $\begin{array}{c}301 \\
(100 \%)\end{array}$ \\
\hline
\end{tabular}


Tab. 6. Vztah mezi trendem studijních výsledků na SŠ a využíváním služeb kariérového poradenství

\begin{tabular}{|l|c|c|c|c|}
\hline & Zlepšují se & Zhoršují se & Zůstávají stejné & Celkem \\
\hline $\begin{array}{l}\text { ANO, } \\
\text { opakovaně }\end{array}$ & $\begin{array}{c}\mathbf{6 0} \\
(\mathbf{4 4} \%)\end{array}$ & $\begin{array}{c}17 \\
(13 \%)\end{array}$ & $\begin{array}{c}58 \\
(43 \%)\end{array}$ & $\begin{array}{c}135 \\
(100 \%)\end{array}$ \\
\hline $\begin{array}{l}\text { ANO, } \\
\text { jednorázově }\end{array}$ & $\begin{array}{c}98 \\
(32 \%)\end{array}$ & $\begin{array}{c}49 \\
(16 \%)\end{array}$ & $\begin{array}{c}160 \\
(52 \%)\end{array}$ & $\begin{array}{c}307 \\
(100 \%)\end{array}$ \\
\hline
\end{tabular}

jí, že se jim studijní výsledky v průběhu studia zhoršovaly, se jednorázovým využitím služeb ( $\mathrm{p}<0,01)$ snaží „zachránit“, co se dá. Je tedy otázkou, jestli zhoršující se prospěch je impulzem k využití služby. Z dalších výsledků vyplývá, že zhoršující se studijní výsledky „nestačí“. K využití služeb kariérového poradenství je potřeba, aby žáci byli se svými studijními výsledky nespokojeni. Ti, kteř́ jsou se svými studijními výsledky nespokojeni, častěji plánují, že služby kariérového poradenství využijí (adjustované reziduum je $+4,4$ ).

Poslední skupinu zdrojů sociální (ne) spravedlnosti, do nichž může využívání služeb „vstoupit“, hledám ve vzdělávacích aspiracích spojených s (ne)spokojenos- tí s volbou studijního oboru a $s$ plánem (ne)pokračovat ve studiu zvoleného oboru nebo (ne)hledat uplatnění $\mathrm{v}$ oboru. Ve skupině těch, kteří opakovaně využili služeb kariérového poradenství, je statisticky více žáků velmi spokojených s volbou svého oboru (adjustované reziduum $\mathrm{v}$ prrípadě opakovaného využití služeb je $+2,2)$. V dalších kategoriích se už ale žádné statisticky významné rozdíly neprokázaly. Neprokázal se ani statisticky významný vztah mezi vzdělávacími aspiracemi (jakého nejvyššího vzdělání chtějí žáci dosáhnout) a tím, jak moc chtějí žáci zůstat v oboru (studovat nebo pracovat).

Snad jediným statisticky významným vztahem ohledně využívání služeb karié-

Tab. 7. Využití služeb kariérového poradenství v závislosti na vzdělávacích aspiracích a uplatnění v oboru

\begin{tabular}{|l|c|c|c|c|c|c|}
\hline $\begin{array}{l}\text { Využití } \\
\text { kariérového } \\
\text { poradenství }\end{array}$ & $\begin{array}{c}\text { Určitě ne } \\
(\mathbf{s t r ̌ e d n i ́} \\
\mathbf{s} \text { VL) }\end{array}$ & $\begin{array}{c}\text { Určitě ne } \\
\text { (střední } \\
\mathbf{s} \text { maturitou) }\end{array}$ & $\begin{array}{c}\text { Určitě ne } \\
\text { (VOŠ) }\end{array}$ & $\begin{array}{c}\text { Určitě ne } \\
\text { (VŠ) }\end{array}$ & $\begin{array}{c}\text { Určitě ne } \\
\text { (ještě } \\
\text { nevím) }\end{array}$ & Celkem \\
\hline $\begin{array}{l}\text { ANO, } \\
\text { opakovaně }\end{array}$ & $7,1 \%$ & $35,7 \%$ & $0 \%$ & $42,9 \%$ & $14,3 \%$ & $100 \%$ \\
\hline $\begin{array}{l}\text { ANO, } \\
\text { jednorázově }\end{array}$ & $3 \%$ & $18,2 \%$ & $\mathbf{9 , 1} \%$ & $\mathbf{6 0 , 6} \%$ & $9,1 \%$ & $100 \%$ \\
\hline NE, plánuji & $13,6 \%$ & $\mathbf{4 0 , 9} \%$ & $\mathbf{4 , 5} \%$ & $29,5 \%$ & $11,4 \%$ & $100 \%$ \\
\hline NE, neplánuji & $11,9 \%$ & $30,4 \%$ & $2,8 \%$ & $37,9 \%$ & $17 \%$ & $100 \%$ \\
\hline
\end{tabular}


rového poradenství je silné přesvědčení nepokračovat ve zvoleném studijním oboru ani $v$ rámci studia, ani z hlediska uplatnění na trhu práce (tab. 7). Pokud jsou žáci přesvědčeni, že určitě nebudou pokračovat ve zvoleném oboru, a mají aspirace získat maturitu, vyšší odborné nebo vysokoškolské vzdělání (Fisher's $p=0,167$ ), pak už jednorázově služeb využili nebo plánují tyto služby využít (Cramer's $V=0,127)$.

\section{DŮVODY VYUŽITÍ SLUŽEB}

\section{KARIÉROVÉHO PORADENSTVÍ}

Dosavadní zjištění o využívání služeb dokreslí důvody, které sami žáci uvedli jako impulzy k vyhledání služby. Nejdříve je potřeba zdůraznit, že ne všichni služby vyhledávali. Část respondentů napsala, že jim byla služba nabídnuta během povinné účasti na aktivitách organizovaných školou (napřr. přednášky a besedy, návštěva pobočky úřadu práce), nebo pro ně představovala zprostředkovanou či náhodnou př́ležitost. O využití či nevyužití služby $\mathrm{v}$ daných prrípadech rozhodovala poslušnost, zvědavost, nebo naopak nuda.

Pokud žáci služby vyhledali, dají se jejich důvody rozdělit do dvou skupin. Společným znakem skupiny důvodů, která vyjadřuje potřeby žáků-klientů ve vztahu k poradenství typu career guidance, se dá vyjádřit jako přání, aby jim někdo poradil ohledně další vzdělávací dráhy nebo jim pomohl při hledání uplatnění na trhu práce. Žáci uváděli, že si potřebovali vyslechnout názor někoho nestranného, nejlépe nestranného odborníka, př́ípadně někoho, koho znají a důvěřují mu, nebo si chtěli ujasnit, co jimi zvažované možnosti obnášejí. Někteří si však radu spojili s potřebou získat další, specifičtější informace. $\mathrm{Za}$ deklarovanými důvody zařazenými do této kategorie je patrná nejistota, pochybnosti či nerozhodnost, která vyplývá $\mathrm{z}$ existence několika stejně atraktivních možností, nebo jsou výrazem neznalosti postupu, jak by žáci mohli svého kariérového cíle dosáhnout. Kritéria rozhodování mají žáci vytvořena (např. aby mě to bavilo, vydělávat dost peněz) a využití služeb chápou jako pojistku při dosahování svých kariérových cílů/plánů/představ. Je zajímavé, že z této skupiny důvodů lze vysledovat i období využití služeb, které kopíruje čas, kdy se žáci rozhodují.

Pro druhou skupinu důvodů vyhledání služeb je typická nerozhodnost vyplývající z rozporuplnosti zájmů, nesouladu osobních předpokladů a nároků, nejistých prognóz vývoje na trhu práce či absence kariérových cílů či představ. Za mnohými rozpory stojí osobní (žáky explicitně uváděné zdravotní) či sociální problémy, které žákům ztěžují či dokonce znemožňují rozhodování a řízení své kariéry. Řešení těchto typů zakázek vyžaduje z hlediska poradenské práce dlouhodobější podporu ze strany poradců (činnosti typu career counselling), což se může projevovat opakovaným využitím služeb. $Z$ výroků žáků je patrné, že služby kariérového poradenství žáci $\mathrm{v}$ tomto př́padě považují za nástroj $\mathrm{k}$ odstraňování bariér (včetně vyřízení nutných formalit a "potvrzení"), s nimiž se dlouhodobě potýkají, nebo za nástroj překonávání překážek, které se jim připletly do života. 
$\mathrm{Z}$ důvodů, které žáky vedly $\mathrm{k}$ využití služeb, je zřejmé, že část žáků využívajících služeb kariérového poradenství nahlíží na tyto služby jako na nástroj svého rozvoje, který má v jejich očích uspokojivý směr či průběh. Jsou ale i tací, kteří vyhledávají služby kariérového poradenství proto, aby díky překonání určitých překážek dali své kariéré žádoucí směr či průběh.

\section{SHRNUTí ZÁVĚRŮ A DISKUZE LIMITŮ}

Z dat vyplývá, že služeb kariérového poradenství typu career guidance a career counselling využívá relativně nízké procento žáků středního odborného vzdělávání, což samo o sobě implikuje otázku, zda uvedených $14 \%$ žáků reprezentuje společenskou „elitu“, nebo naopak „sociálně znevýhodněné“. Nahlédneme-li tuto otázku podle dopadů využití služeb na jedince, pak se $\mathrm{z}$ důvodů využití služeb kariérového poradenství dá vyvodit i to, co žák považuje za žádoucí dopad. Důvody využití služeb naznačují, že pro některé žáky je využití služeb lanovkou $\mathrm{k}$ jejich kariérovým cílům, pro jiné příležitostí ke změně v širokém slova smyslu, pro další jsou nástrojem překonávání překážek a tím i objevení možností, jak svou kariéru nastartovat. Základním limitem pro další rozvíjení odborné diskuze o využívání služeb kariérového poradenství je absence empirických zjištění, a to nejen u nás, ale i v zahraničí.

Zásadním zjištěním ale je, že charakteristiky jedinců, z nichž pramení sociální nerovnosti (pohlaví, dosažené vzdělání...), nesouvisí s využíváním služeb přímo (srov. Balin \& Hirschi, 2010). Naopak se zdá, že služby kariérového poradenství mají díky pestrosti žáků-klientů, kteří je využívají, potenciál přispět $\mathrm{k}$ sociální spravedlnosti řadou způsobů. Pro přehlednost rozděluji množinu žáků, kteří využili služeb kariérového poradenství, do tří skupin.

Jednu skupinu vytvárím $\mathrm{z}$ těch, kteří hodnotí své studijní výsledky nejvyššími stupni klasifikační stupnice, $\mathrm{v}$ průběhu studia se jejich studijní výsledky zlepšují a jsou velmi spokojeni s volbou svého oboru. Tato „konstelace“ charakteristik, s nimiž žáci vstupují do služeb kariérového poradenství, odsuzují služby k vyčkávací taktice, jestli se případná sociální nespravedlnost projeví, nebo ne. Do té doby bude kariérový poradce $s$ klientem pracovat na jeho zakázkách, které v ideálním prrípadě budou kopírovat důvody využití služeb, tj. budou směřovat $\mathrm{k}$ odstranění překážek nebo budou dynamizovat dosavadní kariérový rozvoj, což z hlediska sociálních nerovností bude znamenat reprodukci sociálních nerovností.

Druhou skupinu žáků představují ti, kteří měnili školu v průběhu studia, své aktuální studijní výsledky hodnotí jako dostatečné a jejich prospěch se $\mathrm{v}$ průběhu studia zhoršoval. V tomto prípadě se s ohledem na stejné důvody využití služeb rýsuje možnost vyrovnávat př́padné sociální nerovnosti.

Třetí skupinu žáků-klientů reprezentují ti, kteří určitě nechtějí pokračovat ve zvoleném oboru a mají aspirace získat vyšší vzdělání, než aktuálně studují. U této skupiny lze uvažovat o tom, že by 
služby kariérového poradenství mohly výrazněji prosazovat princip sociální spravedlnosti. Základním omezením a tím i limitem uvedených závěrů je, že rozdělení žáků do skupin je postaveno na deskriptivní statistice.

Proměnnou, která by mohla proměnit roli služeb kariérového poradenství ve vztahu k sociální spravedlnosti, je „všeobecná“ nespokojenost klienta se svou situací. $\mathrm{Na}$ druhou stranu právě nespokojenost obvykle dovede klienta ke kariérovému poradci, tj. k využití služeb, ale již „nezabezpečí, jestli vůbec a př́padně jak budou mít služby kariérového poradenství možnost přispět k sociálně spravedlivější společnosti.

$S$ ohledem na specifika systému odborného vzdělávání a služeb kariérového poradenství v ČR je zřejmé, že kariérové poradenství hraje ve vztahu ke vzdělávacímu systému podpůrnou roli, konkrétně uplatňováním principu rovnosti v přistupu ke vzdělávacím př́ležitostem. Pokud by služby kariérového poradenství měly být nástrojem $\mathrm{k}$ posilování rovnosti vzdělávacích př́ležitostí, pak by s přihlédnutím $\mathrm{k}$ problémům, $s$ nimiž se služby v ČR potýkají, mělo „stačit“, že žákům

- budoucím absolventům odborného vzdělávání jsou poskytovány alespoň nějaké služby kariérového poradenství, což je zabezpečeno implementací kariérového vzdělávání do formálního vzdělávání.

\section{ZÁVĚR}

Cílem této studie bylo identifikovat roli využívání služeb kariérového poradenství ve vztahu k sociální spravedlnosti ve společnosti. Jednotlivé role jsou vyvozeny z charakteristik žáků absolventských ročníků středních odborných škol a středních odborných učilišt, kteří využili služeb kariérového poradenství. Pestrost charakteristik těch, kteří služeb využili, potvrzuje tezi o vysoké heterogenitě této skupiny žáků odborného vzdělávání (srov. CEDEFOP, 2018; Trhlíková \& Úlovcová, 2010), čímž umožňují službám kariérového poradenství zaujmout roli reprodukce i vyrovnávání sociálních nerovností, stejně jako ujmout se prosazování principu rovných vzdělávacích příležitostí. Ve vztahu k charakteristikám žáků-klientů tak všechny tři zmíněné role kariérového poradenství mají dosud nevyužitý potenciál vytvářet spravedlivější podmínky ve společnosti.

\section{LITERATURA}

Balin, E., \& Hirschi, A. (2010). Who seeks career counselling? A prospective study of personality and career variables among Swiss adolescents. International Journal for Educational and Vocational Guidance, 10(3), 161-176.

Borgen, W., \& Hiebert, B. (2006). Career guidance and counselling for youth: Chat adolescents and young adults are telling us. International Journal for the Advancement of Counselling, 28(4), 389-400.

CEDEFOP (2010). Access to success lifelong guidance for better learning and working in Europe. Luxembourg: Publication office of the European Union. Dostupné z www.cedefop.europa.eu 
CEDEFOP (2018). The changing nature and role of vocational education and training in Europe. Volume 5: Education and labour market outcomes for graduates from different types of VET system in Europe. Cedefop Research Paper, 69. Dostupné z www.cedefop.europa.eu Hlad’o, P., \& Drahoňovská, P. (2012). Rozhodováni žáků základnich a strednich škol o dalšim studiu a práci v pohledu žáki i jejich rodiču. Praha: NÚV.

Hloušková, L. (2012). Potreby dospělých ve vztahu k rizeni své kariéry a možnosti jejich uspokojování prostréednictvím služeb kariérového poradenství. Část 1: Motivy a bariéry využiváni služeb kariérového poradenství. Nepublikovaná zpráva z výzkumu podle zadání Centra Euroguidance ČR.

Hloušková, L. (2014). Mám základní vzdělání. Př́ičiny a důsledky předčasných odchodů ze studia a ze vzdělávání. Studia paedagogica, 19(2), 11-38.

Hooley, T. (2014). The evidence base on lifelong guidance: A guide to key findings for effective policy and practice. ELGPN Tools, 3.

Hooley, T., Sultana, R., \& Thomsen, R. (Eds.). (2018). Career guidance for social justice: Contesting neoliberalism. New York: Routledge Taylor \& Francis.

Chamoutová, D., Vojtěch. J., \& Chomová, P. (2017). Analýza realizované vzdèlávaci nabidky střednich škol. Praha: NUV.

Kantorová, J. (2015). Školni klima na školách poskytujicich středni vzdèláni s výučním listem. Olomouc: Univerzita Palackého v Olomouci.

Kuczera, M. (2010). Learning for jobs. OECD Reviews of vocational education and training. Czech Republic. Dostupné z www.oecd.org

MPSV (2017). Pololetni statistiky absolventů škol a mladistvých v evidenci ÚP. Dostupné z https://portal.mpsv.cz

MŠMT (2017). Statistická ročenka školství - výkonové ukazatele. Dostupné z http://toiler.uiv.cz Nařizeni vlády č. 211/2010 Sb., o soustavě oborio vzdèláni v základnim, středním a vyšším odborném vzdělávání. In Sbírka zákonů České republiky, ročník 2010, částka 71, rozeslána dne 30. června 2010, s. 2410-2472.

OECD (2004). Career Guidance: A handbook for policy makers. Paris: OECD. Dostupné $\mathrm{z}$ www.oecd.org

Rámcový vzdělávací program pro základni vzdělávání. (2017). Praha: NÚV.

Strauss, A., \& Corbinová, J. (1999). Základy kvalitativního výzkumu. Postupy a techniky metody zakotvené teorie. Boskovice: Albert.

Sultana, R. (2014). Pessimism of the intellect, optimism of the will? Troubling the relationship between career guidance and social justice. International Journal for Educational and Vocational Guidance, 14(1), 5-19.

Štastnová, P., \& Drahoňovská, P. (2012). Jak žáci základnich a středních škol vybirají svou dalši vzdèlávaci nebo pracovni kariéru. Praha: NÚV.

Trhlíková, J., \& Úlovcová, H. (2010). Učební obory - specifika vzdělávací cesty a uplatnění na trhu práce. In P. Matějů, J. Straková \& A. Veselý (Eds.), Nerovnosti ve vzdělávání. Od měrení k řešeni (s. 180-207). Praha: SLON. 
Veselý, A., \& Matějů, P. (2010). Vzdělávací systémy a reprodukce vzdělanostních nerovností. In P. Matějů, J. Straková \& A. Veselý (Eds.), Nerounosti ve vzdèlávání. Od měrení k řešení (s. 38-90). Praha: SLON. Vojtěch, J., \& Chamoutová, D. (2018). Vývoj vzdèlanostni a oborové struktury žáků a studentu ve střednim a vyšsím odborném vzděláváni $v \check{C} R$ a v krajich $\check{C} R$ a postaveni mladých lidí na trhu práce ve srovnáni se stavem $v$ Evropské unii. Praha: NÚV.

Zákon č. 561/2004 Sb., o predškolnim, základnim, strédnim, vyššim odborném a jiném vzdèláváni (školský zákon). In Sbírka zákonů České republiky, ročník 2004, částka 190, s. 10262-1032. Zákon č. 167/2018 Sb., kterým se méní zákon č. 561/2004 Sb., o préedškolnim, základnim, středním, vyššim odborném a jiném vzdèlávání (školský zákon), ve znění pozdějších předpisů. In Sbírka zákonů České republiky, ročník 2018, částka 86, s. 2610-2611.

Mgr. Lenka Hloušková, Ph.D.

Masarykova univerzita, Filozofická fakulta, Ústav pedagogických véd;

e-mail: hlouskov@phil.muni.cz

\section{HLOUŠKOVÁ, L. The Use of Career Advisory Services by Students at Middle Vocational Schools}

The importance of career advisory services is usually discussed in relation to its value for individuals, but in this study attention is focused on one of the wider social goals of these services, and specifically the question of how career advisory services can contribute to social justice in society.

The goal is to identify the role of career advisory services in tackling social inequalities.

Method: The text is based on data obtained by questionnaire in the course of March and April 2018 among pupils in the final year of full-time studies at middle vocational training centres and middle vocational schools in the South Moravia and Moravian-Silesian regions. The roles of career advisory services are uncovered via statistically significant differences between those who used the services and those who did not as correlated (or not) with gender, subjective rating of educational results, type of completion of studies, and educational aspirations.

Results: 14\% of the 3096 pupil-respondents had consulted a career expert. These services had more frequently been used by pupils who had changed school in the course of their studies, rated their educational results as "one" (i.e. highly) on a scale of classification, had declared an improvement in their educational results in the course of their studies and those with an idea of their educational andlor work future. By contrast pupils who rated their educational results as "sufficient" (i.e. mediocre) or are unsatisfied with their results, more often just plan to use the services of an expert. A one-off consultation with an advisor has more often been sought by those who do not see themselves going into work connected with their field of school studies so far, but have aspirations to achieve a higher level of education than the level they are just finishing.

Conclusion: The findings described suggest that career advisory services have the potential to contribute to social justice via three roles that develop depending on the profiles of pupils-clients and their reason for consulting the service.

Keywords: career advisory service, social justice, pupils in vocational education, higher secondary education. 